\section{SOI: 1.1/TAS DOI: 10.15863/TAS International Scientific Journal Theoretical \& Applied Science}

\author{
p-ISSN: 2308-4944 (print) \\ e-ISSN: 2409-0085 (online) \\ Year: 2017 \\ Issue: 04 \\ Volume: 48
}

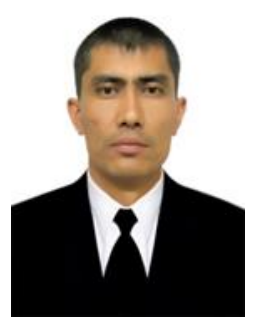

Orifjon Tolibjonovich Nurmatov

reseacher, department of Accounting and audit, Fergana polytechnical institute, imf_azizi83@mail.ru

SECTION 31. Economic research, finance, innovation, risk management.

\title{
MODERNIZATION PROCESS IN UZBEKISTAN: BEFORE AND NOW
}

Abstract: In the following article, essence of modernization was theoretically researched. Historical development of modernization process in Uzbekistan and its potential problems are illustrated.

Key words: modernization, technology, novelty, jadids, human capital, innovation, instructional change.

Language: Russian English

Citation: Nurmatov OT (2017) MODERNIZATION PROCESS IN UZBEKISTAN: BEFORE AND NOW. ISJ Theoretical \& Applied Science, 04 (48): 206-210.

Soi: http://s-o-i.org/1.1/TAS-04-48-33 Doi: crossef https://dx.doi.org/10.15863/TAS.2017.04.48.33

\section{Introduction}

In the 90 s of the previous century, our country's economy was merely based on its natural resources and the majority of the population worked in agricultural sector, which in turn reflected upon socioeconomic life of people. However, in the last quarter of century Uzbekistan has been undergoing huge socioeconomic modernizations, which are purely based on national rituals, demographics of our nation and its natural resources. Consequently, those modernizations are initiating new types of industries, such as cars, electronics to be found. So, what do we mean by modernizations?

As known from history, all great scientists of their periods based their philosophical on economic and political perspectives. The main purposes of those views were developing the society by enhancing craftsmanship, farming, livestock, and military sides of it.

\section{Literature review}

The concept of modernization, later the development of the theory of modernization, was given an impetus by liberation of a number of poor countries in 1950-1960 and democratization of Soviet countries in $1980-90$.

Founders and supporters of modernization theory were O. Könt, G. Spencer, K. Marx, M. Weber, E. Durkheim, and F. Tennis. Their doctrine relied on an assumption that historical development was based on exact progressive phases. Classic Theory originated in the US by U. Rostov, G. Almond, D. Apter, L. Pa, S. Eisenstaedt, S. Haptington, T. Parsons, who learned the potential problems of social modernization. Modernization theory is one of the trends of socio-historical development and originated in the dawn of the New Era. In the literary works of F. Tennis, M. Weber and T. Parsons two types of society are differentiated: traditional and modern.

Modernization theory aimed to explain the process of modernization of the society. Assuming that "traditional" or reactionary societies and countries should be developed to the level of developed ones, the theory previews the internal factors of development of those highly developed countries.Modernization theory tries to find the changes influenced on social development of the society and to expound social evolution processes.

Historical approach, which is based on development, improvement, and occurrence of new process, is referred to as the "modernization" approach. It assumes history as a collection of transitions from traditional to modern society, from agricultural to industrial society. Main purpose of modernization approach is to learn modernization processes.

Usually modernization processes occur in two directions. The first direction is about industrialization process that was based on industrial revolutions in those developed countries; the second direction is about modernization processes in undeveloped countries. "Second-type" modernization process comprises the industrialization process in undeveloped countries. This type of modernization is often observed in the countries, where the need for industrialization is felt. Basics of implementation methods of "second-type" modernization process 
were introduced by a German scientist, and according to him, the country should be first developed culturally on a whole scale. According to sociologists' admiration, basic principles of modernization process are:

- To put an end to hindrances to economic growth, changes in society, and the ongoing national values and to replace them with more modern values;

- To establish systems those encourage innovation in business entities;

- To create new technologies and implement them;

- To establish organizational and economic relations;

Industrialization process in nearly all western countries led to changes in society and in economy, in production growth, and in development of national markets. Thus, in the beginning of $20^{\text {th }}$ century, some concepts spread among scientist, sociologists, and philosophers that they began to influence on national, cultural values, and on other social spheres.

Such changes were based on the western model of modernization, and comprised changing public awareness, its thinking, and its culture. The main essence of those concepts was the importance of implementing ready, practical, political institutions (that were tested in developed countries; such as, centralized government, parliament, multi-partied system, general election process and etc.) and embracing new values (economics and individual freedom).

However, these days' scientists are abandoning the universalistic approach while understanding socio-economic and political development and embracing the originality of Asian, African, and Latin American values in those spheres. Huge attention in learning concrete socioeconomic and political processes is being given to the different societies' individuality, its cultural originality, and historical situations [1].

The main purpose behind development of modernization in new level is taking into account the social, economic structures except western ones. So now scientists do not consider traditional institutions, values, and national rituals as threats to modernization. Thus, when implementing modernization processes, traditional and national values are being considered, while at the same time universal criterion is not also forgotten. Japan, South Korea, Indonesia, Malaysia, Singapore, and Turkey can be possible examples.

In Uzbekistan, initial views on modernization were found during in the end of $19^{\text {th }}$ and in the beginning of $20^{\text {th }}$ centuries by Jadids (new). Main advocators and promoters of Jadid Movement were Munavvarqori Abdirashidov, U. Xujayev, M. Behbudiy, A. Fitrat, F.Xujayev, A. Avloniy, who calles themselves "proponents of progress" and later "Jadids". Feeling that local people are lagging behind by world in terms of development, they realized that the society needed a reform.

The Jadids felt that local people lagged behind from worldwide progressing and they recognized to reform the society.

Most of prominent scientists, modern learned specialists in industry and agricultural field, men of culture were from the Jadids and wished to attain independence and modern homeland and fought for this.

The following tendencies were the most important in the Jadids' fight for independence of Turkistan:

* extending branch of new methodical school;

* sending ability youths to other countries to study;

* organizing various educated societies and theatre groups;

* publishing newspaper and magazines, creating national democratic state in Turkistan with developing social and political surprise of the peoples.

The main ideas and goals of the Jadids are following:

Deliverancing Turkistan from religious prejudice and backwardness which belonged to middle ages, reforming Islamic religious law, giving education to the people, fighting to create autonomy state in Turkistan, creating constitutional autonomy and parliament in Bukhara and Khiva, establishing free and plentiful country by setting democratic Republic, organizing stable national money via army.

At the beginning of last century Mahmudhuja Behbudiy told that "To live in the world one should get knowledge in world science, or nation without it disappear". His action, his goal was to lead to modernize life.

During the former soviet period the modernization process was completed on the sake of Communist empire. The leading industrial enterprises have been moved during the Second World War, and military strategic enterprises were built on those bases. The economy was based on agriculture. Abled persons were $60 \%$, and they were engaged in producing agricultural products. It was the main cause of low living conditions of people. National income was low than other developed countries. According national income Uzbekistan was in the last positions.

The economy of Uzbekistan after gaining the independence was in a very bad condition and improving and leading from economical crisis was difficult task.

To improve economy, to modernize in different spheres different models was offered. But it might have lead undesirable consequences.

\section{Analysis and results}

Social-economic process in the first years of Independence was conducted by "Uzbek model" 
conception which was created by the first President Islam Karimov without improving education system.

It is difficult to improve modernization system in the country. It depends on knowledge level of social subjects.

It is known that education, personal, government social economics, scientific-technical and cultural needs to meet social, humanitarian cultural spheres of development and bring up creative persons who gained knowledge as well as skill.

Modernization process of education system is complex and many-sided process and it is an essential part of social changes of a country transforming from one level of development to another, also it is the process of release from ideology of former colonialist regime. That is why world society is paying special attention to the role and importance of education in the $21^{\text {st }}$ century.

The first President of our country Islam Karimov in his book: "Uzbekistan in the threshold of the $21^{\text {st }}$ century: threats to security, conditions for stability and guarantees of development.", emphasizes that human potential is the key and active factor of establishing successful reforms for prosperity.

For that matter, huge investments have been made into human resources development in our country. Each year our government is spending 10$12 \%$ of GDP for the needs of education system. This figure is almost two times bigger than 6-7\% expenditures level for education sphere recommended by UNESCO in order to maintain long-term prosperity and development. When we configure exact amounts, then we see that if GDP in 2016 was equal to 200 trillion Sums, so we can calculate that government expenditures for education are nearly 20-24 trillion Sums. This amount of money constitutes $50-60 \%$ of annual government budget, which shows how much attention is paid for education, particularly in human capital, on national policy level. As we mentioned above, the future of the country, its gradual development and strong economic base established today will be determined and updated by young professionals who have worldclass education and skills. For that reason, the main objective targeted through reforms in the education system is to educate and prepare new generation of skilled personnel possessing world-class education, keen to social activity, able to independently define correct aims, promoting promising ideas and solve them. As pointed in the "National program of personnel training" we should be guided by Uzbekistan Republic's Law “About Education" principles, which are prepared combining world standards in education and best practices of national experience.

№ UP-4947 "Strategy action plan for the further development of the Republic of Uzbekistan for 2017-
2021" was published by the President of the country Shavkat Mirziyayev on February 7, 2017. "This is the fourth aspect of the strategy of development of the social sector priorities" with a special focus on the development of the education sector, "the development of science and education: continuing education opportunities to continue improving the quality of education services, in accordance with the needs of the modern labor market for highly qualified personnel training; educational institutions, construction, reconstruction, repair them with modern teaching and laboratory equipment, computer equipment and teaching aids equipment to perform their work to strengthen the materialtechnical base of the purposeful measures " .

The President of Republic of Uzbekistan Shavkat Mirziyayev put more stress on modernization in his speech called as "the results of the 2016 socio-economic development of the country and the most important priorities of economic program for the year 2017," the extended session of the Cabinet of Ministers also stated on the priorities for the process of education and training issues, "... More solutions to the problem are also very important: it is the level of professional teachers and professors and teaching staff, their special knowledge. In this regard, the issues of education, spiritual and moral perfection and the actual values in the process of forming the active support are necessary to create an environment". These are important aspects of the process of modernization for the educational process.

We study the aspects of the modernization of the economy based on the traditional economy or administrative command to create a totalitarian economic development with a qualitatively new way - consciously controlled and regulated. In the world experience all types of transitions to a market economy are summarized in the following three main types:

1) the way of the developed countries;

2) the way of the developing countries;

3) the way of the former socialistic countries;

4) the ideas of socialism, with the establishment of an efficient market economy mechanism to carry out (China).

Although these ways are different, they have got common features. Their similarity is that they all aim to transfer to a market economy system, while the economic principles and mechanisms to follow the rules of law are common in many aspects. At the same time, each way has its own features, which may be caused by different social-economical, historical, national conditions of formation of market relations.

For example, in the transition to market relations in the way of the developed countries, subsistence agriculture transforms into classic free competition based or free market economy and then into the modern market economy. 
The main feature of transition to market economy in developing countries, freed from former colonialism is - conversion from traditional and economically backward economy to a free market economy. Finally, the important feature of the way of the former socialistic countries is transition from centralized, administrative-command economy into developed modern market system. This way's difference from others is that the totalitarian economy hasn't common thing with the market economy, they completely contradict each other. However, in the third way, countries transferring to market relations differ from each other with transition conditions, the level of economic development, ownership and managing forms. These are the characteristics of the given path of transition to a market economy.

As shows the world experience it is possible to pass out to the market economy in a revolutionary way, that is, the dynamic method or step-by-step evolutionary way. In the first case, the radical reforms are called up for the sudden and complete breakdown of the previous system of economic relations and is called "shocking therapy" referred to as the method of treatment. Old economic relations could be transformed step-by-step into a new market system, and the establishment of an effective market economy will take place without any damage. Experience shows that the evolutionary path of reforms will lead to less social shocks, are much more gradual and inevitable.

Not only regulated market economy transition ways, but also its standards are also diverse. First of all, they differ in the national characteristics and traditions of different countries where market economy systems are being created. Therefore, some of market economy standards are classified by their particular affiliation to the undertaking country. For example, Germany, South Korea, Turkey, Argentina, Poland templates, and so on.

The importance of transition from an administrative-command economy to a free market economy is crucial by the fact that the need for an extensive access to the factors of economic growth is decreasing while effective capacity of the planned economy diminishing. The transition from administrative-command economy to market economy has general tendency in different countries. This process consists of economic liberalization, deep institutional (primarily ownership relations) changes, however, at the same time calls for the implementation of measures to stabilize the financial system.

The transformation of the administrativecommand system means the fundamental change in the system, and it is transition into higher quality market economy system, that's why we can call such changes as structural reforms.

\section{Conclusions and Recommendations}

Another aspect of modernization processes is upgrading the production. The majority has got some habits about this concept, which is equipping production with modern technology and machinery. Thanks to the reforms to improve the investment climate in the country, many enterprises with foreign investment activities have started to operate. As a result, the existing and newly established business entities, highly efficient, energy-efficient working methods have appeared. In order to provide businessmen with modern, advanced and high-tech equipment and machinery tools our country each year organizes and undertakes exhibitions of equipment and machinery where a lot of domestic and foreign enterprises are presented. Actually, without modernization of production means we cannot guarantee success to produced commodities at our local companies in the world markets. But today we cannot state that operating businesses are using modern and efficient machinery. In particular, the production of leather processing, footwear, textiles, apparel, agricultural products processing enterprises today have morally outdated machines. Without complete implementation of the latest technology in these spheres, the manufactured goods of such enterprises will not deserve any credits in the world markets, moreover their reputation in the domestic market will not last for a long time.

To stimulate modernization of production the legislation in our country is providing several customs, exemptions and tax benefits for imported production equipment and machinery used for own needs. We consider that current incentives are not enough to present-day preferences. We think not only equipment purchased for own needs, but also all imported modern equipment for trading (sell) purpose should meet tax and customs duties privileges. Because as much modern equipment and technologies will enter the country, businesses will create products not only for local market clients, but also they will be able to ensure the global competitiveness in the world market. Only, while introducing exemptions for imported equipment we should measure whether they are up-to-date, from the point of view of developing strategic fields of national economy definite rules must be produced.

Currently, many enterprises feel lack of foreign currency (due to absence of export) or difficulties with currency conversion through commercial banks are in a certain extent preventing them from installing modern equipment.

Without the modernization of production, the problems of exports and currency conversion are difficult to solve. 


\begin{tabular}{l|lrl|l|ll} 
& ISRA (India) & $=\mathbf{1 . 3 4 4}$ & SIS (USA) & $=\mathbf{0 . 9 1 2}$ & ICV (Poland) & $=\mathbf{6 . 6 3 0}$ \\
Impact Factor: & ISI (Dubai, UAE) $=\mathbf{0 . 8 2 9}$ & PUHIL (Russia) $=\mathbf{0 . 2 3 4}$ & PIF (India) & $=\mathbf{1 . 9 4 0}$ \\
& GIF (Australia) & $\mathbf{0 . 5 6 4}$ & ESJI (KZ) & $=\mathbf{3 . 8 6 0}$ & IBI (India) & $\mathbf{= 4 . 2 6 0}$ \\
& JIF & $\mathbf{1 . 5 0 0}$ & SJIF (Morocco) & $=\mathbf{2 . 0 3 1}$ & & \\
\hline
\end{tabular}

\section{References:}

1. Kupryashin GL (1991) Politicheskaya modernization. - M .: Obshchestvoznanie. -p.9.

2. (2002) The National Encyclopedia. Tashkent.

3. Karimov IA (2016) Na rasshirennom zasedanii kabineta ministrov, posvyashennom itogam sotsialno-ekonomicheskogo razvitiya strani $\mathrm{V}$ 2015 godu i vajneyshim prioritetnim napravleniyam ekonomicheskoy programmi na 2016 god. 16 jan. 2016, Tashkent

4. (1997) "National Program of the Republic of Uzbekistan". 27.08.1997 years.

5. (1997) The Law of the Republic of Uzbekistan "On Education". 27.08.1997 years.

6. (2017) The President of the Republic of Uzbekistan "of the Republic of Uzbekistan for the period 2017-2021 on the further development strategy," the decree. February 7, 2017.
7. (2017) The President of the Republic of Uzbekistan Shavkat Mirziyayev the country's socio-economic development in 2016 and the most important priorities of economic program for 2017, the results of the meeting of the Cabinet of Ministers extended

8. Islam Karimov (1993) the transition to market relations in its own way. T . p 23.

9. Karimov IA (2011) «Vse nashi ustremleniya i programmi - vo imya dalneyshego razvitiya rodini i povisheniya blagosostoyaniya naroda» Doklad Prezidenta Respubliki Uzbekistan I.Karimova. 21 yanvarya 2011, g.Tashkent

10. (2016) "Innovative mechanisms of supporting small business" scientific monography: A.Tashpulatov, A. Xojaev - Fergana; "Farg'ona" publisher. - 128 p. 